\title{
The monetary policy transmission mechanism in China
}

\author{
Yi Gang
}

\section{Evolution of monetary policy transmission mechanism}

The People's Bank of China (PBC) began functioning as the central bank in 1984, and since then monetary policy has been used to balance the aggregates. At the time, direct credit controls were used in the conduct of monetary policy, ie direct controls on credit and cash were relied upon to manage and adjust the economy, to prevent inflation and to promote economic growth.

Since the 1990's, the method of financial macro-management has gradually changed. With the abolition of credit ceilings on January 1, 1998, and the expansion of open market operations, monetary policy operations also moved from direct credit control to indirect measures. During this transition, the intermediate and operational targets also switched to money supply and base money, with the adoption of a combination of monetary policy instruments, such as open market operations, reserve requirements, central bank discount, central bank lending and interest rates. An indirect management system has been set up, with stabilizing and promoting economic growth as the final goal and money supply as the intermediate target, through the usage of multiple monetary policy instruments. At the same time, with the development of a money market, a "central bank $\rightarrow$ money market $\rightarrow$ financial institutions $\rightarrow$ enterprises (individuals)" transmission system is taking shape, and progress has been made in developing an indirect transmission mechanism, using monetary policy instruments to influence operational target, and in turn to influence the intermediate target and eventually to achieve the final goal. As a result, the monetary policy management system has also been improved.

\section{Monetary policy transmission relies mainly on an indirect management mechanism}

Recent years have seen the transformation from direct control through administrative measures, such as quotas, to indirect controls through economic measures, while greater priority has been given to building a mechanism for macro-management.

First, monetary policy instruments have been further improved. A framework has been set up in which a combination of open market operations and other instruments such as reserve requirements, central bank lending and rediscount, are used to adjust base money and to manage credit aggregates. The role of open market operations has been strengthened in the daily adjustment of base money and they have become a major instrument.

Second, interest rate system reform has been pushed forward, with the role of interest rates strengthened. The band of deposit and lending rate floating has been further widened, and the lending rate ceiling and deposit rate floor have been abolished. With this improvement of the central bank interest rate system, the central bank is now better able to guide the market interest rate using monetary policy instruments. Financial institutions can make better pricing, and market participants are more sensitive to interest rate changes. This shows that the importance of the interest rate in resource allocation and in transmitting monetary policy has become more apparent. 
Third, the flexibility of the RMB exchange rate has increased as market supply and demand have played a bigger role in the formation of the RMB exchange rate. On July 21, 2005, China adopted a managed floating exchange rate regime based on market supply and demand with a reference to a basket of currencies, putting an end to a basically fixed RMB exchange rate. The experience in the past year indicates that following a self-initiated, controllable and gradual principle in exchange rate regime mechanism reform is the right approach, and the reform has produced good results. Risk management tools such as forward sales and purchases of foreign exchange and swaps have been developed rapidly. Economic agents have increased their awareness of and capacity to manage exchange rate risks and become adaptive to the managed fluctuation of the RMB exchange rate. The growth of exports declines while that of imports goes up. The utilization of foreign capital continues to increase. Economic growth and employment have not suffered any shocks.

Fourth, financial markets have developed stably and the monetary policy transmission mechanism has further improved. The development of financial markets not only directly impacts the transmission of monetary policy but also to a large extent determines the transition toward indirect approaches. In recent years, financial markets have developed rapidly thanks to a number of innovations. A monetary policy transmission process has developed which flows from central bank to financial markets and financial institutions in turn, and impacts real sectors. The financial system continues to develop and improve so that a financial market system with diversified trading locations, products and mechanisms has gradually been formed. Functions of financial markets have been deepened continuously. Participation of market players has increased and more channels are available now. In addition, with financial products and tools multiplying and market size expanding, the efficiency of resource allocation has improved significantly. Institutional building of financial markets has been increasingly strengthened. Major achievements have been made in infrastructure, legal and supervisory framework construction. The openness of financial markets has been enhanced continuously as well. The policy of attracting foreign capital and participation has achieved significant results, while domestic institutions have quickened their paces to go to the overseas market.

Fifth, there has been a breakthrough in financial institution reforms, resulting in heightened incentives for profit maximization and sensitivity to the indirect approach of monetary policy. Overall, the microeconomic foundation of monetary policy transmission has been further reinforced. The reform of state-owned commercial banks has evolved smoothly. After the introduction of strategic investors, state-owned banks have achieved diversification in ownership and clarification in property rights, and a modern corporate governance framework has gradually emerged, along with significant improvement in balance sheets. The pilot reform of rural credit cooperatives has achieved significant progress. Their non-performing loans have declined greatly and capital adequacy ratios increased gradually. Meanwhile, by steadily promoting the reform of the property rights system and transforming the operating mechanism, rural credit cooperatives have also conducted some meaningful experiments in strengthening internal management information disclosure and the legal person governance structure. Reform of other financial institutions has accelerated, with that of postal saving institutions pushed forward steadily. Reform of insurance companies has seen a breakthrough, with the ownership restructuring of state-owned insurance companies largely finished. Reform and restructuring of policy banks, shareholding banks, urban commercial banks and other non-bank financial institutions has also accelerated appreciably.

\section{A further improvement of the monetary policy transmission mechanism}

Although improvements have been made in China's monetary policy transmission mechanism in recent years, some problems still remain. First, the independence of monetary 
policy in macroeconomic management has been constrained to some extent. In recent years, with widening imbalances in international payments and intensified structural imbalances in the Chinese economy, monetary policy has had to face weakened pre-emptiveness and effectiveness in maintaining internal equilibrium. Second, it is more difficult for monetary policy to be conducted with money supply as the intermediate target. Although price instruments have had a strengthened role in monetary policy, monetary policy operations still rely heavily on quantitative management aimed at adjusting money supply. With further enhancements in financial innovation and the introduction of financial derivatives, a monetary policy transmission mechanism with money supply as its intermediate target will face more challenges.

In order to solve the existing problems in monetary policy transmission, in addition to domestic economic structural adjustment, on the part of the monetary policy, we need to promote a shift from quantitative instruments to price instruments, further improve the exchange rate regime, and continue to push ahead steadily with market-based interest rate reform, so as to enable price instruments such as the interest rate and exchange rate to play a sufficient role in monetary policy transmission.

First, improving the RMB exchange rate formation regime. Based on the need of China's economic and financial development and stability, market demand and supply will be given a fundamental role in RMB exchange rate regime formation, according to the principle of a selfinitiated, controllable and gradual approach, to improve the managed floating exchange rate regime and maintain RMB exchange rate basically stable at an adaptive and equilibrium level. In addition, the reform of the foreign exchange management system will be speeded up by establishing and strengthening the market mechanism and management system for international payments so as to promote BOP equilibrium and support balanced and sustained growth of the overall economy.

Second, steadily advancing market-based interest rate reform. We will enhance the leverage role of interest rates in monetary policy transmission, further harmonize the relationship among central bank policy interest rates, financial market rates and deposit and lending rates of commercial banks, encourage financial institutions to promote liquidity management capability, improve their sensitivity to macro management measures by the central bank, and gradually set up an interest rate transmission mechanism through which financial institutions price their loans with reference to market rates and market rates move in response to central bank benchmark rate adjustments. The recent development of Shibor (Shanghai interbank offer rate) is an encouraging sign for interest rate liberalisation

Third, pushing forward the reform of state-owned commercial banks and rural credit cooperatives. We will continue to promote share-holding reform of state-owned commercial banks, and turn them into modern financial institutions with adequate capital, strict internal control, secure operation and good services and profitability. The rural financial services system will be improved by developing rural credit cooperatives into local financial institutions with a clearly established ownership structure, scientific management, strengthened disciplinary mechanism and financial sustainability, providing services to the rural economy on a commercial basis.

Fourth, promoting further financial market development. We will improve the existing financial products, standardize operational procedures for financial instruments, and increase the width and depth of the financial market through financial innovation. We will also implement a supervisory policy that encourages financial innovation, establish fair market rules for such innovation, and actively foster a social environment in favor of financial innovation under the precondition of risk prevention. Efforts will be made to develop direct financing, broaden linkages between the money market and the capital market, improve the efficiency of monetary policy transmission in the capital market, further promote the resource allocation function of the financial system and foster the formation of real capital price signals. 